\title{
Strategi Pengelolaan Pajak Daerah Dalam Upaya Peningkatan PAD di Kota Serang
}

\author{
Pancawati Sugiharti Multiningsih ${ }^{1}$, Arenawati ${ }^{2}$, \\ Rina Yulianti ${ }^{3}$ \\ 1,2,3Pascasarjana, Magister Administrasi Publik, Universitas Sultan Ageng Tirtayasa. \\ Jl. Raya Serang Jakarta Km 3, Panancangan, Kec. Cipocok Jaya, Serang, Banten 42124
}

\section{ART I C LE IN F O}

\section{Article history:}

Received 11/11/2021

Received in revised form 18/11/2021

Accepted 18/11/2021

\begin{abstract}
This study focuses on the analysis of local tax management strategies in an effort to increase PAD in Serang City. The theory uses SWOT analysis according to Hunger (2017: 23) which includes factors of strength (strength), weakness (weakness), opportunities (opportunities) and threats (threats). The research method uses case studies. The research approach uses a qualitative approach with a qualitative descriptive design. Research informants from BPKAD elements of Serang City, secretary of Commission III DPRD Serang City for Finance and Regional Assets, and hotel, restaurant and entertainment companies. Data analysis using data analysis techniques Miles and Huberman. The results of the study show that the SO (Strenghs to Opportunity) strategy is by adding local tax services that are carried out online, and adding new local taxpayers through data collection activities or direct surveys to the location of business activities engaged in hotels, restaurants and entertainment, WO strategy (Weakness to Opportunity) by adding field officers to carry out data collection and survey activities for business actors, especially small and medium-sized businesses that have not been registered as local taxpayers, ST Strategy (Strenghs to Threats) by utilizing the Serang City BPKAD website to periodic reporting of local taxes to the public, the WT (Weakness to Threats) strategy by means of publicity of local tax information can utilize print media and electronic media.
\end{abstract}

Keywords: Regional Tax Management Strategy; PAD; Serang City.

\begin{abstract}
Abstrak
Penelitian ini berfokus kepada analisis strategi pengelolaan pajak daerah dalam upaya peningkatan PAD di Kota Serang. Teori menggunakan analisis SWOT menurut Hunger (2017:23) yang meliputi faktor kekuatan (strengh), kelemahan (weakness), peluang (opportunities) dan ancaman (threat). Metode penelitian menggunakan studi kasus. Pendekatan penelitian menggunakan pendekatan kualitatif dengan desain deskriptif kualitatif. Informan penelitian dari unsur BPKAD Kota Serang, sekretaris Komisi III DPRD Kota Serang Bidang Keuangan dan Aset Daerah, dan perusahaan hotel, restoran dan hiburan. Analisis data menggunakan teknik analisis data Miles dan Huberman. Hasil penelitian diketahui strategi S-O (Strenghs to Opportunity) dengan cara penambahan pelayanan pajak daerah yang dilakukan secara online, dan penambahan wajib pajak daerah baru melalui
\end{abstract}


kegiatan pendataan atau survei secara langsung ke lokasi kegiatan usaha yang bergerak di bidang hotel, restoran dan hiburan, strategi W-O (Weakness to Opportunity) dengan cara penambahan petugas lapangan untuk melaksanakan kegiatan pendataan dan survei pelaku usaha, khususnya usaha yang tergolong kecil dan menengah yang belum terdata sebagai wajib pajak daerah, Strategi S-T (Strenghs to Threats) dengan cara memanfaatkan situs website BPKAD Kota Serang untuk pelaporan pajak daerah kepada publik secara berkala, strategi W-T (Weakness to Threats) dengan cara publisitas informasi pajak daerah dapat memanfaatkan media cetak dan media elektronik.

Kata kunci : Strategi Pengelolaan Pajak Daerah; PAD; Kota Serang.

*)Pancawati Sugiharti Multiningsih

E-mail : panca.sutawijaya@yahoo.com

\section{PENDAHULUAN}

Pajak berperan penting sebagai sumber pendapatan negara yang dipergunakan untuk membiayai pelaksanaan dan peningkatan pembangunan nasional untuk mencapai kemakmuran dan kesejahteraan masyarakat (Kurniawati \& Toly, 2014). Guna mewujudkan tujuan tersebut, pemerintah tentunya memerlukan sumber dana yang memadai dalam membiayai belanja negara, membiayai program pembangunan hingga membiayai sarana dan prasarana umum seperti alat transportasi, stasiun, dan jalan raya dan fasilitas publik lainnya yang salah satunya diperoleh dari hasil penerimaan pajak.

Bagi suatu daerah, pajak daerah menjadi salah satu unsur pembentuk Pendapatan Asli Daerah (PAD), salah satunya terhadap PAD pada pemerintah daerah tingkat Kabupaten dan Kota di Provinsi Banten. Siahaan (Siahaan, 2017) menyatakan PAD adalah penerimaan yang diperoleh dari sektor pajak daerah, retribusi daerah, hasil perusahaan milik daerah, hasil pengelolaan kekayaan daerah yang dipisahkan dan lain-lain pendapatan sah. Menurut Undang-undang Nomor 33 Tahun 2004 tentang Perimbangan Keuangan Antara Pusat dan Daerah Pasal 1 ayat 18 menyatakan bahwa PAD adalah pendapatan yang diperoleh daerah yang dipungut berdasarkan peraturan daerah sesuai dengan peraturan perundangundangan yang berlaku. Mardiasmo (Mardiasmo, 2009) menyatakan PAD menunjukkan kemampuan pemerintah daerah dalam menggali sumber daya dan potensi keuangan suatu daerah.

Realisasi pajak daerah pada tingkat Kabupaten dan Kota di Provinsi Banten pada tahun 2020 disajikan lebih lanjut pada tabel sebagai berikut : 
Tabel 1. Realisasi Pajak Daerah Kabupaten dan Kota di Provinsi Banten Tahun 2020 (Milyar Rupiah)

\begin{tabular}{|l|r|}
\hline \multicolumn{1}{|c|}{ Kabupaten / Kota } & \multicolumn{1}{c|}{ Realisasi Pajak Daerah } \\
\hline Kabupaten & Rp. $78.631 .042 .426,00$ \\
\hline Pandeglang & Rp. 73.671.154.478,00 \\
\hline Lebak & Rp. $1.836 .701 .000,000,00$ \\
\hline Tangerang & Rp. 337.253.848.564,00 \\
\hline Serang & Rp. $1.566 .739 .000 .000,00$ \\
\hline Kota & Rp. 455.921.1426.128,00 \\
\hline Tangerang & Rp. 148.393.407.446,00 \\
\hline Cilegon & Rp. $1.330 .046 .267 .606,00$ \\
\hline Serang &
\end{tabular}

Sumber : Data diolah peneliti, 2021

Berdasarkan Tabel 1, diketahui realisasi penerimaan pajak daerah pada tiap Kabupaten dan Kota di Provinsi Banten memperoleh realisasi yang berbeda-beda. Pada tingkat Kabupaten, Kabupaten Tangerang menempati urutan teratas dengan realisasi pajak daerah terbesar, sedangkan Kabupaten Lebak menempati urutan terbawah dengan realisasi pajak daerah terendah. Apabila pada tingkat Kota, Kota Tangerang menempati urutan teratas dengan realisasi pajak daerah terbesar, dan Kota Serang menempati urutan terbawah dengan realisasi pajak daerah terendah. Realisasi pajak daerah pada tingkat Kota Serang yang menempati urutan terbawah bila dibandingkan dengan Kota lainnya di Provinsi Banten mendasari untuk menetapkan lokasi penelitian di Kota Serang.
Jenis pajak daerah Kota Serang sebanyak 9 jenis pajak, diketahui bahwa pajak daerah yang bersinggungan langsung dengan unit usaha, dalam hal ini perusahaan yang bergerak pada bidang pelayanan jasa yang berdampak langsung kepada kegiatan perekonomian di Kota Serang adalah pajak hotel dengan kontribusi sebesar 2,71\%, pajak restoran dengan kontribusi sebesar $12,15 \%$, dan pajak hiburan dengan kontribusi sebesar 0,86\%. Pajak hotel, pajak restoran dan pajak hiburan yang dikenakan pada perusahaan bidang jasa tersebut juga dapat menstimulasi pendapatan pajak daerah lainnya, seperti pajak reklame, pajak parkir, dan pajak air tanah yang disebabkan oleh adanya aktivitas dari perusahaan bidang jasa tersebut. Selain itu, secara kontribusi dari pajak hotel, pajak restoran dan pajak hiburan memberikan kontribusi yang cukup signifikan terhadap penerimaan pajak daerah bagi Pemerintah Kota Serang (Sumber: Laporan 
Pertanggungjawaban Bendahara Penerimaan SKPD SPJ Pendapatan Administratif Pemerintah Kota Serang. 2020).

Berdasarkan hasil observasi, diketahui terdapat permasalahan yang diduga menjadi penghambat bagi BPKAD Kota Serang dalam melaksanakan tugasnya mengelola pajak daerah dalam rangka meningkatkan Pendapatan Asli Daerah, khususnya pajak pada tingkat kota yang mencakup pajak hotel, pajak restoran dan pajak hiburan. Hal ini mengingat secara kontribusi, pajak hotel, pajak restoran dan pajak hiburan memberikan kontribusi yang cukup signifikan terhadap penerimaan pajak daerah bagi Pemerintah Kota Serang, dimana Kota Serang sebagai ibukota Provinsi Banten dengan fokus pembangunan ekonomi berbasis kepada perdagangan dan jasa (Sumber: Laporan Pertanggungjawaban Bendahara Penerimaan SKPD SPJ Pendapatan Administratif Pemerintah Kota Serang. 2020). Meski demikian, perusahaan yang bergerak di bidang jasa perhotelan, restoran dan hiburan menjadi salah satu sektor yang terdampak langsung dari adanya pandemi Covid-19 yang melanda hampir seluruh Negara di dunia, termasuk Negara Indonesia mulai dari awal tahun 2020 sampai dengan penelitian ini berlangsung di tahun 2021. Lebih lanjut, permasalahan tersebut diuraikan lebih lanjut sebagai berikut ini.

Pertama, tidak adanya kegiatan pendataan atau survei secara langsung dari petugas BPKAD Kota Serang terhadap wajib pajak di lapangan sehingga tidak diketahui secara pasti data terbaru (update) dari wajib pajak hotel, restoran dan hiburan di tingkat Kota Serang. Hal disebabkan tidak adanya petugas khusus yang berasal dari unsur BPKAD Kota Serang dan atau pihak ketiga yang ditunjuk oleh BPKAD Kota Serang untuk mendata langsung wajib pajak di lapangan (Sumber: Hasil Wawancara dengan Bapak Aris selaku Pegawai BPKAD Bidang Pendapatan, Hari Senin, Tanggal 11 Januari 2021).

Pentingnya petugas khusus pendataan menyadari pada setiap tahunnya memungkinkan adanya penambahan maupun pengurangan jumlah wajib pajak yang mempengaruhi penetapan pagu atau target anggaran setiap tahunnya. Selain itu, tidak adanya pendataaan langsung kepada wajib pajak di lapangan menyebabkan rendahnya kesadaran wajib pajak yang belum terdata sebagai wajib pajak untuk segera mengurus kelengkapan dokumen perpajakan atas usaha yang dilaksanakannya guna bisa mendapatkan Nomor Pokok Wajib Pajak Daerah (NPWPD) sebagai bukti bahwa mereka telah terdaftar sebagai Wajib Pajak Daerah dan memiliki tanggung jawab serta kewajibannya untuk membayar sesuai dengan usaha yang dimilikinya. Hal ini disebabkan oleh kelalaian dari pejabat atau pimpinan BPKAD Kota Serang Bidang Pendapatan yang tidak melaksanakan fungsi pendataan secara faktual kepada wajib pajak di lapangan sehingga masyarakat tidak mengerti proses dan tata cara serta tahapan untuk mendapatkan NPWPD tersebut.

Kedua, pelayanan pajak masih mengandalkan kepada pelayanan secara langsung di kantor BPKAD Kota Serang saja dinilai menyulitkan wajib pajak. Pada dasarnya, pelayanan perpajakan secara langsung di kantor BPKAD Kota Serang didasarkan kepada organisasi terkait sudah memiliki bagian dan 
seksi yang memadai dalam pelayanan terkait pajak dan keuangan daerah, adanya kecukupan sumber daya manusia untuk melayani wajib pajak, ketersediaan sarana dan prasarana kerja, dan regulasi yang mengatur pelayanan langsung dalam Peraturan Walikota Serang Nomor 25 Tahun 2017 Tentang kedudukan, susunan organisasi, tugas dan fungsi serta tata kerja BPKAD Kota Serang.

Pelayanan secara langsung di era teknologi berbasis internet dinilai kurang memberikan kemudahan kepada wajib pajak untuk mengurus pembayaran pajaknya karena harus datang ke lokasi kantor BPKAD Kota Serang sehingga menyebabkan wajib pajak akhirnya menunda pembayaran pajaknya walaupun wajib pajak harus membayar denda atas keterlambatannya (Sumber: Hasil Wawancara dengan Bapak Ma'ruf selaku wajib pajak hotel, Hari Senin, Tanggal 11 Januari 2021). Pembayaran pajak hotel, restoran dan hiburan di Kota Serang belum bisa dilakukan secara online, padahal tata kelola pemerintahan daerah saat ini sudah mengusung penerapan $E$ Governance (Elektronics Governance) yang mendasari instansi pemerintah dalam pelayanan publik dapat memanfaatkan teknologi informasi dan komunikasi berbasis internet (online), dimana pada lingkup Provinsi Banten dilandasi oleh Peraturan Daerah Nomor 6 Tahun 2018 Tentang Penyelenggaraan Komunikasi dan Informatika.

Ketiga, belum terintegrasinya tiping box (alat perekaman bukti transaksi pendapatan dari wajib pajak) secara online serta belum seluruhnya wajib pajak terpasang tiping box karena keterbatasan alat tersebut yang dimiliki oleh BPKAD Kota Serang yang saat ini berjumlah sebanyak 50 tiping box, dimana minimnya tiping box tersebut menyulitkan dalam verifikasi data jumlah pajak dari wajib pajak (Sumber: Hasil Wawancara dengan Ibu Fatma selaku Bendahara BPKAD Bidang Pendapatan, Hari Selasa, Tanggal 12 Januari 2021). Hal ini bertujuan untuk mengetahui apakah jumlah pajak yang dilaporkan sudah sesuai dengan jumlah transaksi pendapatan yang direkam dalam alat tiping box. Selain itu, tidak terintegrasinya tiping box juga akan menyulitkan kerjasama dan koordinasi dengan pihak-pihak terkait, diantaranya Diskominfo, BPKAD, KPK atau BPK.

Keempat, kurangnya sosialisasi langsung dan tidak langsung yang dilakukan oleh petugas BPKAD Kota Serang terhadap wajib pajak di Kota Serang. Dalam sosialisasi langsung ditunjukkan dari petugas jarang melakukan sosialisasi kepada wajib pajak yang belum terdata atau terdaftar untuk melengkapi dokumen persyaratan pajaknya agar dapat mengurus kewajiban pajaknya serta mendapatkan pelayanan publik terkait dengan usahanya dari pemerintah daerah. Sedangkan dalam sosialisasi secara tidak langsung ditunjukkan dari tidak adanya pemasangan alat promosi berupa spanduk atau reklame di jalan arteri maupun di lokasi lain yang strategis dan banyak dilalui oleh masyarakat sehingga masyarakat mengetahui informasi perpajakan (Sumber: Hasil Wawancara dengan Bapak Yomi selaku Wajib Pajak Restoran, Hari Selasa, Tanggal 12 Januari 2021).

Kelima, rendahnya kesadaran Wajib Pajak membayar pajak tepat waktu. Hal ini mengingat sistem pemungutan pajak yang digunakan oleh pemerintah Indonesia adalah self assessment system dengan prinsip, dimana pemerintah memberikan 
kepercayaan penuh kepada Wajib Pajak untuk melaksanakan kewajiban perpajakan atas dasar kesadaran dan tanggung jawabnya sebagai warga negara. Setiawan (2018:174) menyatakan self assessment system menekankan kepada setiap Wajib Pajak untuk berperan aktif membayar pajaknya, mulai dari mendaftar diri sebagai Wajib Pajak, mengisi SPTPD (Surat Pemberitahuan Pajak Daerah), menghitung besarnya pajak terutang hingga menyetorkan kewajiban pajaknya kepada instansi terkait. Kelemahan self assessment system diantaranya peluang Wajib Pajak untuk melaporkan data pajak yang fiktif atau tidak sesuai dengan pajak yang sebenarnya, peluang terjadinya penggelapan pajak hingga menyebabkan rendahnya kesadaran Wajib Pajak membayar pajaknya, khususnya pembayaran pajak tepat waktu.

\section{METODE PENELITIAN}

Metode penelitian ini menggunakan metode studi kasus. Bogdan (Bogdan, Robet, Biklen, 2007; Bogdan \& Knopp, 2003) menyatakan bahwa studi kasus merupakan pengujian terhadap satu latar atau satu orang subyek atau satu tempat penyimpanan dokumen atau satu peristiwa tertentu. Kasus pada penelitian ini terkait strategi pengelolaan pajak daerah yang diantaranya bersumber dari pajak hotel, restoran dan hiburan dalam upaya peningkatan Pendapatan Asli Daerah (PAD) di Kota Serang yang dilaksanakan oleh Badan Pengelolaan Keuangan dan Aset Daerah (BPKAD) Kota Serang.

Pendeketan penelitian ini menggunakan pendekatan kualitatif. Jenis data yang digunakan dalam penelitian ini ialah jenis data primer dan sekunder. Sumber data primer diperoleh dari observasi dan wawancara. . Informan kunci (key informan) yang peneliti tetapkan dalam penelitian ini adalah dari unsur BPKAD Kota Serang dan Komisi III DPRD Kota Serang Bidang Keuangan dan Aset Daerah. Sedangkan informan sekunder (secondary informan) adalah wajib pajak badan yang terdiri dari wajib pajak usaha perhotelan, wajib pajak usaha restoran dan wajib pajak usaha jasa hiburan di Kota Serang.

Teknik analisis data menggunakan teknik analisis data kualitatif. Miles dan Huberman dalam (Mafaza \& Setyowati, 2020) mengemukakan aktivitas analisis dilakukan secara interaktif dan berlangsung terus-menerus sehingga datanya jenuh. Tahapan kegiatan analisis data diantaranya pengumpulan data (data collection), reduksi data (data reduction), penyajian data (data display) dan kesimpulan/verifikasi (conclusions drawing/verification).

$\begin{array}{ccr}\text { Pada } & \text { penelitian } & \text { kualitatif, } \\ \text { validitas } & \text { merupakan } & \text { derajat }\end{array}$ ketepatan antara data yang terjadi dengan data yang di laporkan oleh peneliti (Sugiyono, 2016). Untuk menguji validitas data menggunakan teknik Triangulasi data yang merupakan teknik pemeriksaan keabsahan data yang memanfaatkan sesuatu yang lain. Diluar data itu untuk keperluan pengecekan atau sebagai pembanding terhadap data itu. Untuk itu teknik triangulasi data menggunakan teknik Triangulasi Sumber.

\section{HASIL DAN ANALISIS}

Strategi yang diperoleh dari hasil inventarisir faktor intenal, meliputi faktor kekuatan (strenght), kelemahan (weakness), peluang (opportunity), dan ancaman (threat) 
akan menjadi acuan dibuatnya TOWS Matriks, TOWS Matriks (TOWS hanya kebalikan atau kata lain dalam ungkapan SWOT) mengilustrasikan bagaimana peluang dan ancaman pada lingkungan eksternal dapat dipadukan dengan kekuatan dan kelemahan dari organisasi, sehingga hasil yang diperoleh dapat digambarkan melalui empat sel alternatif strategi. Organisasi dapat melaksanakan strategi Strenghts to Opportunity (SO), strategi Strenghts to Threats (ST), strategi Weakness to Opportunity (WO), atapun strategi Weakness to Threats (WT). (Haerah, 2017; Hasanusi, 2015; M, 2019) Organisasi juga harus berani memilih bebeerapa strategi yang kritikal dan memberikan dampak bagi organisasi, yakni BPKAD Kota Serang dalam pengelolaan dan pelayanan pajak daerah, diantaranya pajak hotel, restoran dan hiburan sebagai upaya peningkatan Pendapatan Asli Daerah (PAD) Kota Serang yang akan diuraikan pada tabel sebagai berikut:

\section{Analisis SWOT}

\section{Faktor-Faktor Internal dan Faktor- Faktor Eksternal}

\section{Strengths (S)}

- Pelayanan pajak daerah, yakni hotel, restoran, dan hiburan dilakukan secara langsung di kantor BPKAD Kota Serang sudah dilaksanakan dengan baik

- Ketersediaan sumber daya untuk pelayanan secara langsung pajak sudah memadai

- Prosedur pelayanan mudah dipahami dan dapat dilalui oleh wajib pajak

- Sikap dari aparatur / petugas sudah menunjukkan profesionalitas dalam bekerja
- Masih adanya kesadaran dari wajib pajak hotel, restoran dan hiburan

\section{Weakness (W)}

- Tidak adanya petugas lapangan untuk melakukan survei dan pendataan pengusaha yang belum terdata sebagai wajib pajak daerah

- Pelayanan pajak hotel, restoran dan hiburan saat ini belum bisa dilakukan secara online

- Minimnya sosialisasi pajak daerah secara langsung kepada masyarakat

- Tidak adanya penggunaan media cetak untuk menunjang sosialisasi seperti spanduk atau reklame di jalan raya dan lokasi strategis

- Minimnya penggunaan media elektronik sebagai sarana sosialisasi, seperti penggunaan videotron, iklan layanan masyarakat di televisi lokal, penggunaan situs resmi pemerintah, facebook, instagram atau konten video youtube

- Situs resmi pemerintah belum dioptimalkan dalam transparansi informasi publik dalam bentuk pelaporan data pajak daerah secara berkala maupun pelaporan wajib pajak daerah yang sudah dan yang belum membayar pajak daerah

- Belum semua wajib pajak mendapakan tiping box

- Tiping box belum terintegrasi secara online ke dalam data base BPKAD Kota Serang

- Seringnya perusahaan terlambat membayar pajak dengan mengakumulasikan atau merapel pembayaran pajak

- Masyarakat yang punya kegiatan usaha tidak mau mendaftar sebagai wajib pajak daerah karena minimnya sosialisasi 


\section{Opportunity (0)}

- Peluang menyelenggarakan pelayanan pajak secara online

- Penambahan wajib pajak daerah baru, khususnya untuk usaha yang bergerak di bidang restoran, seperti warung tegal, warung pecel lele, seafood, angkringan yang memiliki toko atau lokasi usaha yang legal

- Pemberian informasi perpajakan kepada wajib pajak daerah dengan cara memberikan brosur atau leaflet kepada perusahaan atau usaha yang belum terdata sebagai wajib pajak

- BPKAD Kota Serang dapat menjalin koordinasi dengan dinas Dinas Koperasi dan UMKM untuk membantu mempermudah pengurusan legalitas usaha dari kegiatan usaha makanan yang belum terdaftar sebagai usaha mikro, kecil, dan menengah untuk penambahan objek pajak daerah

- Penyebarluasan informasi pajak daerah kepada publik dapat dilakukan dengan memanfaatkan teknologi berbasis internet

- Pemerintah Kota Serang telah menetapkan kebijakan penghapusan denda untuk pajak tingkat Kota Serang untuk menstimulasi pertumbuhan usaha di Kota Serang di masa pandemi Covid-19

\section{$\underline{\text { Strategi S-O }}$}

- Penambahan pelayanan pajak daerah yang dilakukan secara online

- Penambahan wajib pajak daerah baru melalui kegiatan pendataan atau survei secara langsung ke lokasi kegiatan usaha yang bergerak di bidang hotel, restoran dan hiburan
- Membuat leaflet dan brosur terkait informasi pajak daerah yang didistribusikan kepada kegiatan usaha yang belum terdaftar sebagai wajib pajak daerah

- BPKAD Kota Serang menjalin kerjasama lintas instansi dengan Dinas Koperasi dan UMKM untuk membantu melegalkan kegiatan usaha mikro, diantaranya kegiatan usaha makanan yang berbasis di toko-toko di pinggir jalan raya sebagai legalitas formal agar dapat menjadi objek pajak daerah

- Pemanfaatan sumber daya instansi yang mendukung publisitas informasi perpajakan kepada publik berbasis elektronik

- Melakukan publisitas kepada wajib pajak daerah tentang adanya penghapusan denda untuk menstimulasi wajib pajak daerah untuk mau membayar pajak daerahnya

\section{Strategi W-0}

- Penambahan petugas lapangan untuk melaksanakan kegiatan pendataan dan survei pelaku usaha, khususnya usaha yang tergolong kecil dan menengah yang belum terdata sebagai wajib pajak daerah

- Penambahan pelayanan pajak daerah secara online

- Melakukan sosialisasi kepada wajib pajak daerah, baik secara langsung dan secara tidak langsung

- Publisitas informasi pajak daerah dapat memanfaatkan media cetak, seperti spanduk dan reklame

- Publisitas informasi pajak daerah dapat memanfaatkan media elektronik, seperti videotron, iklan layanan masyarakat di stasiun televisi lokal, optimalisasi situs website instansi, penggunaan 
media sosial facebook, instagram hingga membuat konten youtube

- Optimalisasi distribusi tiping box kepada waijb pajak yang belum mendapatkan sebagai penguat pelayanan secara online

- Integrasi tiping box secara online dengan data base BPKAD Kota Serang sebagai alat rekam transaksi dari kegiatan usaha wajib pajak daerah guna mencegah kecurangan dalam pelaporan pajaknya

- Memberikan tambahan sanksi bagi wajib pajak daerah yang terbukti telat bayar pajak 3 kali secara berturut-turut maupun yang mengakumulasikan pembayaran pajaknya, seperti memasang spanduk di lokasi usaha wajib pajak daerah yang menerangkan kegiatan usaha tersebut telat membayar pajaknya secara berturut-turut guna meningkatkan kesadaran membayar pajak tepat waktu dan memberikan efek jera

\section{Threats (T)}

- Belum adanya petugas yang melakukan survei menyebabkan penetapan target penerimaan pajak menjadi kurang optimal

- Belum termanfaatkannya pelayanan elektronik membuat masyarakat dan pengusaha selaku wajib pajak daerah tidak dapat ditingkatkan kesadarannya membayar pajak

- Kurangnya sosialisasi, baik langsung dan tidak langsung menyebabkan masyarakat dirinya memiliki kewajiban perpajakan

- Tidak adanya penghargaan atau reward dari BPKAD Kota Serang kepada pengusaha yang membayar pajaknya tepat waktu menyebabkan pengusaha mudah mengabaikan pembayaran pajak
- Minimnya rilis informasi pelaporan perpajakan secara berkala kepada publik membuat ketidakpercayaan publik atas pengelolaan pajak daerah

Kurangnya kesadaran wajib pajak daerah untuk mau membayar pajak secara berkala tiap bulan

\section{Strategi S-T}

- Penambahan petugas lapangan untuk melaksanakan kegiatan pendataan dan survei pelaku usaha yang belum terdata sebagai wajib pajak daerah

- Optimalisasi pelayanan pajak daerah secara online

- Melakukan sosialisasi secara langsung kepada wajib pajak daerah, seperti penyuluhan kepada perhimpunan atau asosiasi pengusaha hotel, restoran dan hiburan untuk meningkatkan kesadaran wajib pajak atas pemenuhan kewajiban pajak

- Memberikan penghargaan dalam bentuk cinderamata / suvernir kepada wajib pajak yang membayar pajak daerahnya tepat waktu

Memanfaatkan situs resmi BPKAD Kota Serang untuk pelaporan pajak daerah sebagai bentuk transparansi informasi publik

\section{Strategi W-T}

- Penambahan petugas lapangan untuk melaksanakan kegiatan pendataan dan survei pelaku usaha, khususnya usaha yang tergolong kecil dan menengah yang belum terdata sebagai wajib pajak daerah

- Penambahan pelayanan pajak daerah secara online

- Melakukan sosialisasi kepada wajib pajak daerah, baik secara langsung dan secara tidak langsung 
- Publisitas informasi pajak daerah dapat memanfaatkan media cetak dan media elektronik

\section{KESIMPULAN}

Hasil penelitian mengenai strategi pengelolaan pajak daerah, meliputi pajak hotel, restoran dan hiburan dalam upaya peningkatan PAD di Kota Serang yang dilaksanakan oleh BPKAD Kota Serang dengan menggunakan analisis SWOT menurut Hunger (Hallett, Wheelen, \& Hunger, 1990; Suriyankietkaew \& Petison, 2020) menghasilkan alternatif strategi yang diuraikan sebagai berikut ini :

\section{Strategi S - 0 (Strenghs to Opportunity)}

Strategi mengutamakan kekuatan untuk memanfaatkan peluang atau strategi SO meliputi: (1) Penambahan pelayanan pajak daerah yang dilakukan secara online, (2) Penambahan wajib pajak daerah baru melalui kegiatan pendataan atau survei secara langsung ke lokasi kegiatan usaha yang bergerak di bidang hotel, restoran dan hiburan, (3) Membuat leaflet dan brosur terkait informasi pajak daerah yang didistribusikan kepada kegiatan usaha yang belum terdaftar sebagai wajib pajak daerah, (4) BPKAD Kota Serang menjalin kerjasama lintas instansi dengan Dinas Koperasi dan UMKM untuk membantu melegalkan kegiatan usaha mikro, diantaranya kegiatan usaha makanan yang berbasis di toko-toko di pinggir jalan raya sebagai legal formal agar dapat menjadi objek pajak daerah, (5) Pemanfaatan sumber daya instansi yang mendukung publisitas informasi perpajakan kepada publik berbasis elektronik, dan (6) Melakukan publisitas kepada wajib pajak daerah tentang adanya penghapusan denda untuk menstimulasi wajib pajak daerah untuk mau membayar pajak daerahnya.

2. Strategi W - O (Weakness to Opportunity)

Strategi meminimalisir kelemahan untuk memanfaatkan peluang atau strategi WO meliputi: Penambahan petugas lapangan untuk melaksanakan kegiatan pendataan dan survei pelaku usaha, khususnya usaha yang tergolong kecil dan menengah yang belum terdata sebagai wajib pajak daerah, (2) Penambahan pelayanan pajak daerah secara online, (3) Melakukan sosialisasi pajak daerah, baik secara langsung dan secara tidak langsung, (4) Publisitas informasi pajak daerah dapat memanfaatkan media cetak, seperti spanduk dan reklame, (5) Publisitas informasi pajak daerah dapat memanfaatkan media elektronik, seperti videotron, iklan layanan masyarakat di stasiun televisi lokal, optimalisasi situs website instansi, penggunaan media sosial facebook, instagram hingga membuat konten youtube, (6) Optimalisasi distribusi tiping box kepada waijb pajak yang belum mendapatkan sebagai penguat pelayanan secara online, (7) Integrasi tiping box secara online dengan data base BPKAD Kota Serang sebagai alat rekam transaksi dari kegiatan usaha wajib pajak daerah guna mencegah kecurangan dalam pelaporan pajak, dan (8) Memberikan tambahan sanksi bagi wajib pajak daerah yang terbukti telat bayar pajak 3 kali secara berturut-turut maupun yang mengakumulasikan pembayaran pajaknya, seperti memasang spanduk di lokasi usaha wajib pajak daerah yang 
menerangkan usaha tersebut telat membayar pajaknya secara berturut-turut guna meningkatkan kesadaran membayar pajak tepat waktu dan memberikan efek jera.

3. Strategi S - T (Strenghs to Threats) Strategi mengutamakan kekuatan dalam mengatasi ancaman meliputi: (1) Penambahan petugas lapangan untuk melaksanakan kegiatan pendataan dan survei pelaku usaha yang belum terdata sebagai wajib pajak daerah, (2) Optimalisasi pelayanan pajak daerah secara online,

Melakukan sosialisasi secara langsung kepada wajib pajak daerah, seperti penyuluhan kepada perhimpunan atau asosiasi pengusaha hotel, restoran dan hiburan untuk meningkatkan kesadaran wajib pajak atas pemenuhan kewajiban pajak, (4) Memberikan penghargaan dalam bentuk cinderamata / suvernir kepada wajib pajak yang membayar pajak daerah tepat waktu, dan (5) Memanfaatkan situs website BPKAD Kota Serang untuk pelaporan pajak daerah kepada publik.

4. Strategi W - T (Weakness to Threats)

Strategi menimalisir kelemahan untuk mengatasi ancaman meliputi: (1) Penambahan petugas lapangan untuk melaksanakan kegiatan pendataan dan survei pelaku usaha, khususnya usaha yang tergolong kecil dan menengah yang belum terdata sebagai wajib pajak daerah, (2) Penambahan pelayanan pajak daerah secara online, (3)
Melakukan sosialisasi kepada wajib pajak daerah, baik secara langsung dan secara tidak langsung, dan (4) Publisitas informasi pajak daerah dapat memanfaatkan media cetak dan media elektronik.

\section{REFERENSI}

Bogdan, Robet, Biklen, K. S. (2007). Qualitative research for education: an introduction to theories and methods / Bogdan, Robert; Biklen, Sari Knopp I download. Alien and Bacon, Inc, New York.

Bogdan, R., \& Knopp, S. (2003). Qualitative Research for education: An Introduction to Theory and Methods. In Qualitative Research.

Haerah, K. (2017). Strategi Peningkatan Pendapatan Asli Daerah Dari Sektor Pajak Hotel Dan Restoran Di Kabupaten Jember. NASPA Journal, 42(1).

Hallett, D. J., Wheelen, T. L., \& Hunger, J. D. (1990). Strategic Management and Business Policy (3rd Edition). The Journal of the Operational Research Society, 41(1).

https://doi.org/10.2307/25829 45

Hasanusi. (2015). Analisis Strategi Peningkatan Pendapatan Asli Daerah (PAD) di Kabupaten Lampung Barat. Jurnal Magister Manajemen, 01(1).

Kurniawati, M., \& Toly, A. A. (2014). Analisis Keadilan Pajak, Biaya Kepatuhan, dan Tarif Pajak terhadap Persepsi Wajib Pajak Mengenai Penggelapan Pajak di Surabaya Barat. TAX \& ACCOUNTING REVIEW, 4(2).

M, N. S. (2019). STRATEGI PENINGKATAN PENDAPATAN ASLI DAERAH (PAD) MELALUI INTENSIFIKASI DAN 
EKSTENSIFIKASI PENERIMAAN

PAJAK DAN RETRIBUSI DAERAH

DI KABUPATEN ENREKANG.

JAKPP (Jurnal Analisis Kebijakan

\& Pelayanan Publik).

https://doi.org/10.31947/jakpp.

v1i1.6500

Mafaza, A., \& Setyowati, K. (2020). COLLABORATIVE GOVERNANCE DALAM PENGEMBANGAN DESA WISATA. Jurnal Kebijakan Publik, 11(1).

https://doi.org/10.31258/jkp.11 .1.p.7-12

Mardiasmo. (2009). Akutansi Sektor Publik. Yogyakarta: Andi.

Siahaan, M. P. (2017). Pajak Daerah dan Retribusi. Jakarta: Raja Grafindo Persada. Retrieved from https://www.rajagrafindo.co.id/ produk/pajak-daerah-danretribusi/

Sugiyono. (2016). Sugiyono, Metode Penelitian. Sugiyono.

Suriyankietkaew, S., \& Petison, P. (2020). A retrospective and foresight: Bibliometric review of international research on strategic management for sustainability, 1991-2019. Sustainability (Switzerland). https://doi.org/10.3390/SU120 10091 